\title{
Prescribed Fire, Soil, and Plants: Burn Effects and Interactions in the Central Great Basin
}

\author{
Benjamin M. Rau, ${ }^{1}$ Jeanne C. Chambers, ${ }^{2}$ Robert R. Blank, ${ }^{3}$ and Dale W. Johnson ${ }^{4}$
}

\begin{abstract}
Authors are ${ }^{1}$ Graduate Research Assistant, University of Nevada, Reno, Hydrolologic Sciences Program, 1000 Valley Rd, Reno, NV 89512, USA; ${ }^{2}$ Research Ecologist, USDA Forest Service RMRS, 920 Valley Rd, Reno, NV 89512, USA; ${ }^{3}$ Soil Scientist, USDA ARS, 920 Valley Rd, Reno, NV 89512, USA; and ${ }^{4}$ Soil Scientist, University of Nevada, Reno, Department of Natural Resources and Environmental Science, 1000 Valley Rd, Reno, NV 89512,
\end{abstract} USA.

\begin{abstract}
Pinyon and juniper expansion into sagebrush ecosystems results in decreased cover and biomass of perennial grasses and forbs. We examine the effectiveness of spring prescribed fire on restoration of sagebrush ecosystems by documenting burn effects on soil nutrients, herbaceous aboveground biomass, and tissue nutrient concentrations. This study was conducted in a central Nevada woodland and included control and burn treatment plots sampled before and after a prescribed fire. Six native understory plant species (Crepis acuminata, Eriogonum umbellatum, Eriogonum elatum, Poa secunda secunda, Festuca idahoensis, and Lupinus argenteus) important for native sagebrush obligate foragers were chosen to represent the understory plant community. $L$. argenteus is also important for system nutrient cycling and nitrogen fixation. Plants were collected from three microsites (under tree canopy, under shrub canopy, and interspace) common in transitional woodlands during peak growth the summer before a spring prescribed burn and each of two summers following the burn. Soils were collected from corresponding locations at two depth intervals $(0-8$ and $8-52 \mathrm{~cm}$ ) to determine the relationships between soil and plant nutrients following fire. Microsite affected soil nutrients but did not influence plant tissue concentrations with the exception of $F$. idahoensis. Burning resulted in increases in soil surface $\mathrm{NH}_{4}^{+}, \mathrm{NO}_{3}^{-}$, inorganic $\mathrm{N}, \mathrm{Ca}^{2+}, \mathrm{Mn}^{2+}$, and $\mathrm{Zn}^{2+}$. Increases in $\mathrm{NO}_{3}^{-}$, inorganic $\mathrm{N}$, and $\mathrm{Zn}^{2+}$ were also observed in deeper horizons. Burning did not affect aboveground plant biomass or nutrient concentrations in the first year with the exception of F. idahoensis, which had increased tissue P. By the second year, all species had statistically significant responses to burning. The most common response was for increased aboveground plant weight and tissue $\mathrm{N}$ concentrations. Plant response to burning appeared to be related to the burn treatment and the soil variables surface $\mathrm{K}^{+}, \mathrm{NO}_{3}^{-}$, and inorganic $\mathrm{N}$.
\end{abstract}

\section{Resumen}

La expansión de Pinyon y enebro en los ecosistemas de artemisa resultan en la disminución de cobertura y biomasa de gramíneas perennes y especies herbáceas. Hemos examinamos la efectividad del fuego prescrito en la primavera para la restauración de los ecosistemas de artemisa mediante la documentación'de los efectos de la quema sobre los nutrientes del suelo, la biomasa'herbácea aérea, y las concentraciones de nutrientes en el tejido. Este estudio fue realizado en un bosque central de Nevada. Se muestrearon parcelas tratadas y de control antes y después de los fuegos prescritos. Seis especies de plantas nativas (Crepis acuminados, Eriogonum umbellatum, Eriogonum elatum, Poa secunda secunda, Festuca idahoensis, y Lupinus argenteus), importantes para especies forrajeras obligadas, fueron escogidas para representar a la comunidad de plantas del sotobosque. L. argenteus es también una especie importante para el ciclo nutritivo del sistema y la fijación de nitrógeno. Las plantas se recolectaron de tres micrositios (bajo la cubierta arbórea, bajo el dosel arbustivo, y el espacio intermedio) comunes en bosques de transición durante el crecimiento máximo de verano antes de una quema prescrita de primavera y cada uno de los dos veranos después de la quema. Los suelos fueron recolectados'de los mismos sitios con'dos intervalos'de profundidad (0-8 y $8-52 \mathrm{~cm}$ ) para determinar las relaciones entre el suelo y los nutrientes de las plantas subsiguientes a la quema. El micrositio afectó los nutrientes del suelo, pero no influyo en las concentraciones en el tejido de la planta, con excepción de F. idahoensis. La quema resultó en un incremento de $\mathrm{NH}_{4}^{+}, \mathrm{NO}_{3}^{-}, \mathrm{N}$ inorgánico, $\mathrm{Ca}^{2+}, \mathrm{Mn}^{2+}$, y $\mathrm{Zn}^{2+}$ en la superficies del suelo. Los aumentos de $\mathrm{NO}_{3}^{-}, \mathrm{N}$ inorgánicos, y $\mathrm{Zn}^{2+}$ fueron también observados en los horizontes más profundos. La quema no afectó la biomasa de la planta sobre la superficie o las concentraciones de nutrientes en el primer año, con excepción de F. idahoensis que había aumentado el P en el tejido. Para el segundo año, todas las especies tenían'respuestas estadísticamente significativas a la quema. La respuesta más común fue el aumento de peso aéreo de la planta y las concentraciones de $\mathrm{N}$ en el tejido. La respuesta de la planta a la quema parece estar relacionada al tratamiento de la quema y a las variables de la superficie en suelo de $\mathrm{K}^{+}, \mathrm{NO}_{3}^{-}$, y $\mathrm{N}$ inorgánico.

Key Words: plant nutrition, prescribed fire, soil nutrients, woodland encroachment

\section{INTRODUCTION}

Research was funded by the USDA Forest Service Rocky Mountain Research Station, Great Basin Ecosystem Management Project, and Joint Fire Sciences Program Project 01B-3-3-01.

Correspondence: Benjamin M. Rau, University of Nevada, Reno, Hydrolologic Sciences Program, 1000 Valley Rd, Reno, NV 89512, USA. Email: brau@unr.nevada.edu

Manuscript received 20 April 2007; manuscript accepted 2 December 2007.
Much of the Great Basin is currently dominated by sagebrush ecosystems. At intermediate elevations, sagebrush ecosystems are increasingly influenced by encroachment of pinyon and juniper trees (Miller and Tausch 2001). Although pinyonjuniper woodlands have expanded and receded several times 
over the past $5000 \mathrm{yr}$, the current rate of expansion is unprecedented. Less than $10 \%$ of current woodlands are older than $140 \mathrm{yr}$ (Miller and Tausch 2001). The recent rapid expansion of pinyon pine (Pinus monophylla Torr. \& Frém.) and juniper (Juniperus osteosperma Torr.) is due to a combination of warming after the little ice age, fire suppression, and overgrazing by livestock (Miller and Wigand 1994; Gruell 1999; Miller and Rose 1999). As pinyon and juniper stands mature, competition for available resources increases, most understory vegetation is eliminated, and the landscape becomes more susceptible to catastrophic wildfire due to increases in woody fuel loads (Reiner 2004).

Prescribed fire has been suggested as a mechanism for slowing pinyon and juniper expansion, preventing catastrophic wildfire, and restoring understory vegetation quantity and quality. This benefits native animal species dependent on sagebrush ecosystems (Connelly et al. 2004). Little information currently exists about fire's effect on understory vegetation or about plant-soil interactions following fire, especially in semiarid regions. Burning in semiarid environments can result in increased available nutrients and reduce competition for resources from woody species (Sturgis 1993). Burning has been shown to increase available soil N, P, Ca, Mg, Mn, and $\mathrm{Zn}$ in semiarid systems (Covington and DeBano 1988; DeBano and Klopatek 1988; Blank et al. 1994a, 1996). However, the overall effects of burning on soil resources may differ as tree expansion and stand maturation progress. Soil responses to burning differ among undershrub, undertree, and interspace cover types in pinyon woodlands because of the effects of islands of fertility and differences in both fine and woody fuels among cover types.

Burning increases nutrient content of understory vegetation (Sturgis 1993; Blank et al. 1994b; Cook et al. 1994), but the mechanisms are not greatly explored. Previous studies of understory vegetation response to prescribe fire in arid regions show that results depend on burn severity and climatic conditions following fire. Cook et al. (1994) found that production of perennial herbs was two times greater on burned than control sites following both prescribed and wildfire in sagebrush communities. They also concluded that perennial herb crude protein levels were higher through late summer for $2 \mathrm{yr}$ following fire (Cook et al. 1994). Blank et al. (1994b) found that native and exotic shrubs and grasses had more aboveground biomass and higher concentrations of $\mathrm{N}, \mathrm{P}$, and $\mathrm{SiO}_{2}$ when grown on previously burned soils. All species sampled in Spanish Mediterranean shrubland were found to have higher concentrations of mineral nutrients immediately after fire but to experience steady declines over time (Carreira and Niell 1992). Following burning on a central Florida sand dune, three of four herb species exhibited increased vegetative growth and flowering and tissue concentrations of $\mathrm{N}$ and $\mathrm{P}$ (Anderson and Menges 1997). Four months after burning in Australian subtropical semiarid grassland, concentrations of $\mathrm{N}$ and $\mathrm{P}$ were higher in aboveground plant material, but total aboveground biomass did not increase because of drier-thannormal conditions (Bennett et al. 2002).

Numerous studies in agronomy have described direct plantsoil relationships to fertilizer treatments. However, few studies examine wildland soils and their quantitative relationship to plant nutrition (Hayati and Proctor 1990).
In this study, we examined the soil chemistry and aboveground biomass and nutrient concentrations of understory grasses and forbs following a spring prescribed burn in a central Great Basin pinyon-juniper woodland. Because of the importance of islands of fertility, climatic conditions, and time since fire, we examined both spatial (cover type) and temporal (before and each of $2 \mathrm{yr}$ following burning) effects. We chose control and burn treatment sites containing a mixture of tree, shrub, and interspace cover types typical of expanding woodlands and sampled soils and herbaceous vegetation on both sites and all cover types before and after the prescribed burn. We hypothesized 1) that cover type influences soil nutritional characteristics and that understory vegetation chemistry should reflect these differences; 2) that burning should have an interaction with the island-of-fertility effect and understory vegetation chemistry in heterogeneous landscapes; and 3) that soil nutritional quality will have direct measurable relationships with plant chemistry.

\section{MATERIALS AND METHODS}

\section{Study Area}

The study is a Joint Fire Sciences Program demonstration area in the Shoshone Mountain Range on the Humboldt-Toiyabe National Forest (Austin Ranger District) in Nye and Lander counties, Nevada. Underdown Canyon (lat $39^{\circ} 15^{\prime} 11^{\prime \prime} \mathrm{N}$, long $\left.117^{\circ} 35^{\prime} 83^{\prime \prime} \mathrm{W}\right)$ is oriented east to west and contains infrequent springs and an ephemeral stream near the top of the drainage. Average annual precipitation ranges from $23 \mathrm{~cm}$ at the bottom to $50 \mathrm{~cm}$ at the top of the drainage and arrives mostly as winter snow and spring rains. Average annual temperature recorded in Austin, Nevada, ranges from $-7.2^{\circ} \mathrm{C}$ in January to $29.4^{\circ} \mathrm{C}$ in July. Lithology of the Shoshone range consists of welded and nonwelded silica ash flow tuff. Soils developed on alluvial fans in this study are classified as coarse loamy, mixed, frigid, typic Haploxerolls (Rau et al. 2005). The soils are extremely coarse grained and have weak to moderate structure.

The vegetation is characterized by sagebrush (Artemisia tridentata vaseyana [Rydb.] Boivin) and single leaf pinyon (Pinus monophylla) with lesser cover of Utah juniper (Juniperus osteosperma). Herbaceous species include the grasses Poa secunda secunda J. Presl, Elymus elymoides Swezey, Stipa comata Trin. \& Rupr., Festuca idaboensis Elmer, and Pseudoroegneria spicata (Pursh) A. Löve and the forbs Eriogonum umbellatum Torr., Eriogonum ovalifolium Nutt., Eriogonum elatum Dougl. ex Benth., Eriogonum heracleoides Nutt., Crepis acuminata Nutt., Phlox longifolia Nutt., Agoseris glauca (Pursh) Raf., Lupinus argenteus Pursh, and Penstemon species. Bromus tectorum, an invasive annual grass, is not a large component of the study area. The vegetation occurs in patches of variable tree dominance typical of intermediate-ageclass woodlands in the central Great Basin. Tree dominance ranges from low $\left(12 \%\right.$ cover, $\left.2152 \mathrm{~kg} \cdot \mathrm{ha}^{-1}\right)$ to high $(74 \%$ cover, $14213 \mathrm{~kg} \cdot \mathrm{ha}^{-1}$; Reiner 2004).

Yearly average precipitation measured over the 3-yr study period (2001-2003) in a standing rain gauge ranged from 27 to $34 \mathrm{~cm}$ during the water year. Precipitation was similar among years with most precipitation arriving between 15 October and 15 April. Little rain $(1-5 \mathrm{~cm})$ fell during the active growing season (15 April-16 July). 


\section{Study Design and Data Collection}

The study was a split-plot design with repeated measures. Study sites $\left(\approx 4 \mathrm{ha} \cdot\right.$ site $\left.^{-1}\right)$ were located on northeast-facing alluvial fans at elevations of 2195 and $2225 \mathrm{~m}$. The two sites were located on adjacent alluvial fans approximately $500 \mathrm{~m}$ apart. The control was located at $2195 \mathrm{~m}$. The burned site was located at $2225 \mathrm{~m}$ and was burned by US Department of Agriculture Forest Service fire personnel on 11-14 May 2002 under favorable weather conditions (air temp $<32^{\circ} \mathrm{C}$, relative humidity $>15 \%$, wind speed $<9 \mathrm{~m} \cdot \mathrm{s}^{-1}$, and gravimetric fuel moisture $\approx 40 \%$ ). Because soil and fuel moisture were relatively high during the time of burning, the vegetation and duff were consumed in patches creating a landscape of burned and unburned islands. Four subplots $\left(0.1 \mathrm{ha} \cdot \mathrm{plot}^{-1}\right)$ were sampled on both the control and the burn study sites. Plots were characterized by intermediate tree cover $\left(38 \%\right.$ cover, $\left.6722 \mathrm{~kg} \cdot \mathrm{ha}^{-1}\right)$ and contained a mix of trees, shrubs, and interspaces. This tree cover represents the transition phase from shrub-dominated systems to tree-dominated systems and may represent a threshold for understory vegetation recovery following fire (Tausch and West 1995). Subsampled plots were further split by microsite (undertree, undershrub, and interspace).

Soil samples were collected from all sites, plots and microsites at four depths $(0-8,8-23,23-38$, and $38-52 \mathrm{~cm})$ using a $10-\mathrm{cm}$ bucket auger and represent the $\mathrm{A}_{1}$ horizon and subsequent 15$\mathrm{cm}$ increments. Samples were collected during early November 2001, 2002, and 2003. All soil was brought back to the lab, airdried, and sieved to $2 \mathrm{~mm}$. Subsamples were analyzed for DTPA $(0.005 \mathrm{M})$ extractable metals, $\mathrm{KCl}(2.0 \mathrm{M})$ extractable $\mathrm{NH}_{4}^{+}$ and $\mathrm{NO}_{3}^{-}, \mathrm{NaHCO}_{3}(0.5 \mathrm{M})$ ortho-P, and $\mathrm{NH}_{4} \mathrm{OAc}(1 \mathrm{~N})$ extractable metals (Lindsay and Norwell 1978; Keeney and Nelson 1982; Olsen and Sommers 1982; Thomas 1982). Extractable metals were determined using atomic absorption and atomic emission spectrophotometry. Extractable $\mathrm{NH}_{4}^{+}$and $\mathrm{NO}_{3}^{-}$were determined using flow injection, the sum of $\mathrm{NH}_{4}^{+}$ and $\mathrm{NO}_{3}^{-}$nitrogen is considered inorganic $\mathrm{N}$, and ortho-P was determined using molybedenate-blue chemistry. Data were then transformed into $\mathrm{kg} \cdot \mathrm{ha}^{-1}$ by using the formula:

$$
\mathrm{kg} \cdot \mathrm{ha}^{-1}=(\mathrm{d})(\mathrm{Db})[1-(>2 \mathrm{~mm} \%)](\text { Conc })(F)
$$

where $\mathrm{d}=$ depth $(\mathrm{cm})$ of the soil horizon, $\mathrm{Db}=$ bulk density $\left(\mathrm{g} \cdot \mathrm{cm}^{-3}\right)$ of that horizon, $>2 \mathrm{~mm} \%$ is the volume percentage coarse fragment of that horizon, Conc $=$ nutrient concentration $\left(\mu \mathrm{g} \cdot \mathrm{g}^{-1}\right)$, and $F=$ conversion factor $\left(0.1 \mathrm{~cm}^{2} \cdot \mu \mathrm{g}^{-1}\right)$.

Five understory plant species were chosen for sampling because of their value as forage to native animals: Eriogonum umbellatum, Eriogonum elatum, C. acuminata, F. idahoensis, and Poa secunda secunda (Barnett and Crawford 1994; Drut et al. 1994; Fischer et al. 1996). A sixth species was chosen for its importance to ecosystem nutrient cycling and $\mathrm{N}$ fixation, $L$. argenteus (Hainds et al. 1999; Hendricks and Boring 1999). Plant sampling was conducted at similar phenology (peak biomass with flowers or seed heads) in June 2001, 2002, and 2003 to determine temporal, spatial, and burn treatment differences in understory plant biomass and nutrient concentration. Two adult plants of each species were collected adjacent to soil sampling locations at each of the three microsites. Although the six plant species considered in this study are common in the area, they are not abundant; therefore, the plants collected were those closest to soil sample locations or were the only available individuals within the subplots. Shears were used to remove all aboveground biomass. Eriogonum umbellatum and Eriogonum elatum did not occur under trees and were sampled only in interspace and undershrub microsites.

Plants were returned to the lab and dried at $60^{\circ} \mathrm{C}$ for $48 \mathrm{~h}$ and then weighed. Dried plant samples were ground in an $\mathrm{Udi}^{\mathrm{TM}}$ mill. All samples were placed in a desiccator for $72 \mathrm{~h}$ prior to analyses. Approximately $0.5 \mathrm{~g}$ of dry plant material was placed into a crucible, ashed in a muffle furnace for $4 \mathrm{~h}$ at $500^{\circ} \mathrm{C}$, solubilized with $20 \mathrm{~mL}$ of $1.0 \mathrm{~N} \mathrm{HCl}$ solution, and diluted with deionized water in a 100-ml volumetric flask (Miller 1998). Extractable metals were determined using atomic absorption and atomic emission spectrophotometry (Miller 1998). Solution $P$ was determined using vanomolybdenate-blue chemistry (Miller 1998). Plant total $\mathrm{N}$ was determined using a standard Kjeldahl digest and flow injection chemistry (Horneck and Miller 1998).

\section{Statistical Analyses}

The Kolmogorov-Smirnov test was used to test for data normality. All data were natural log transformed to meet the assumption that the data were normally distributed.

Data were evaluated using SAS ${ }^{\mathrm{TM}}$ mixed-effects models with repeated measures. Overall differences in available soil nutrients between control and treatment sites, microsites, depths, and years were evaluated with treatment as a main effect, microsite as a split plot within treatment, depth as a split-split plot within treatment and microsite, and year as a split-split-split plot within treatment, microsite, and depth (Appendix A). Because most treatment effects occurred within the top $8 \mathrm{~cm}$ of soil and "depth" was a significant factor in the overall analysis of variance (ANOVA) for each soil nutrient evaluated, we split the soil profile into two depth increments for further analyses $(0-8$ and $8-52 \mathrm{~cm})$. For the soil profile, $\mathrm{kg} \cdot \mathrm{ha}^{-1}$ was calculated as the sum of the three depths $8-23$, 23-38, and $38-52 \mathrm{~cm}$. Treatment effects were evaluated at each depth by considering year and treatment as main effects. Means comparisons were made with Duncan's test $(P<0.05)$ after confirming significant main effects and interactions with the mixed models $(P<0.05)$.

Overall differences in plant nutrients and weights between control and treatment sites, microsites, species, and years were evaluated by considering treatment as a main effect, microsite as a split plot within treatment, species as a split-split plot within treatment and microsite, and year as a split-split-split plot within treatment, microsite, and species (Appendix B). Because "species" was a significant factor in the overall ANOVA for all measured plant variables, treatment effects were assessed at the species level by considering year and treatment as main effects. Means comparisons were made with Duncan's test $(P<0.05)$ after confirming significant main effects and interactions with the mixed models $(P<0.05)$.

Relationships between soil and plant nutrients among all species were explored using SAS ${ }^{\mathrm{TM}}$ canonical correspondence procedures (Ter Braak 1986). Soil surface and soil profile 


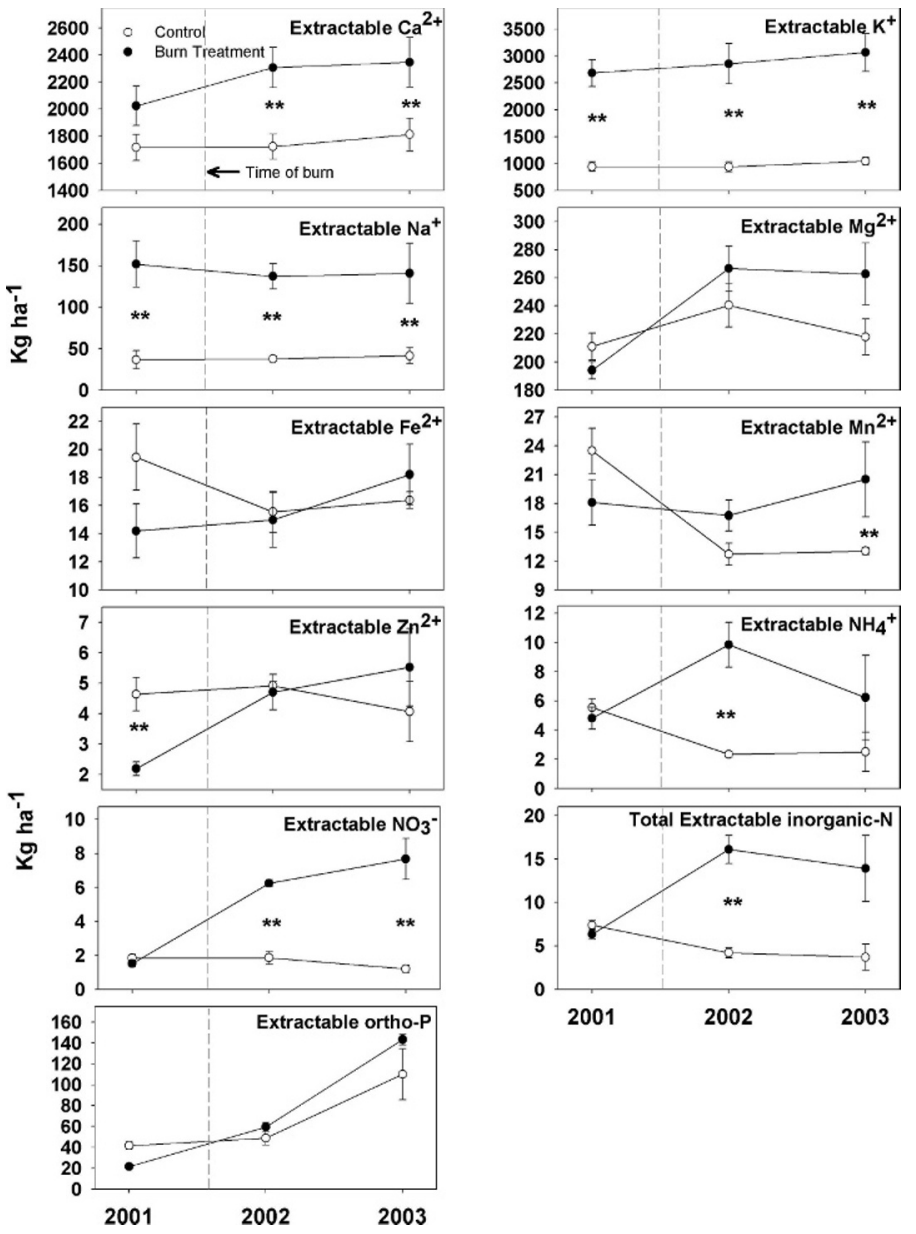

Figure 1. Mean extractable soil nutrient contents $\left(\mathrm{kg} \cdot \mathrm{ha}^{-1}\right)$ and standard errors in 2001, 2002, and 2003 for the soil surface $(0-8 \mathrm{~cm})$ at the control $(2195 \mathrm{~m})$ and burned $(2225 \mathrm{~m})$ sites. Asterisks indicate differences between sites.

variables were used as predictors for the plant variables. All vegetation collected from the control site as well as vegetation collected from the burn site before the burn occurred was designated "unburned." Vegetation collected from the burn site after the prescribed burn was designated "burned." Because it is difficult to separate the effect of woody vegetation removal and fire-induced soil changes on understory plant characteristics, we created a binary variable named "treatment." This binary variable was used as a predictor to take into account all attributes related to burning not measured in this study. Unmeasured variables that may fall into this category include soil water content, competition for mineral nutrients, shading from overstory vegetation, soil temperature, and removal or production of organic compounds that inhibit or promote vegetation or microbial communities (Sturges 1993; Neary et al. 1999; Certini 2005).

\section{RESULTS}

\section{Spatial, Temporal, and Burning Effects on Soils}

Near-soil-surface $\mathrm{K}^{+}$and $\mathrm{Na}^{+}$contents were higher on the burn site before and after burning $\left(P<0.05\right.$; Fig. 1). Surface $\mathrm{Zn}^{2+}$

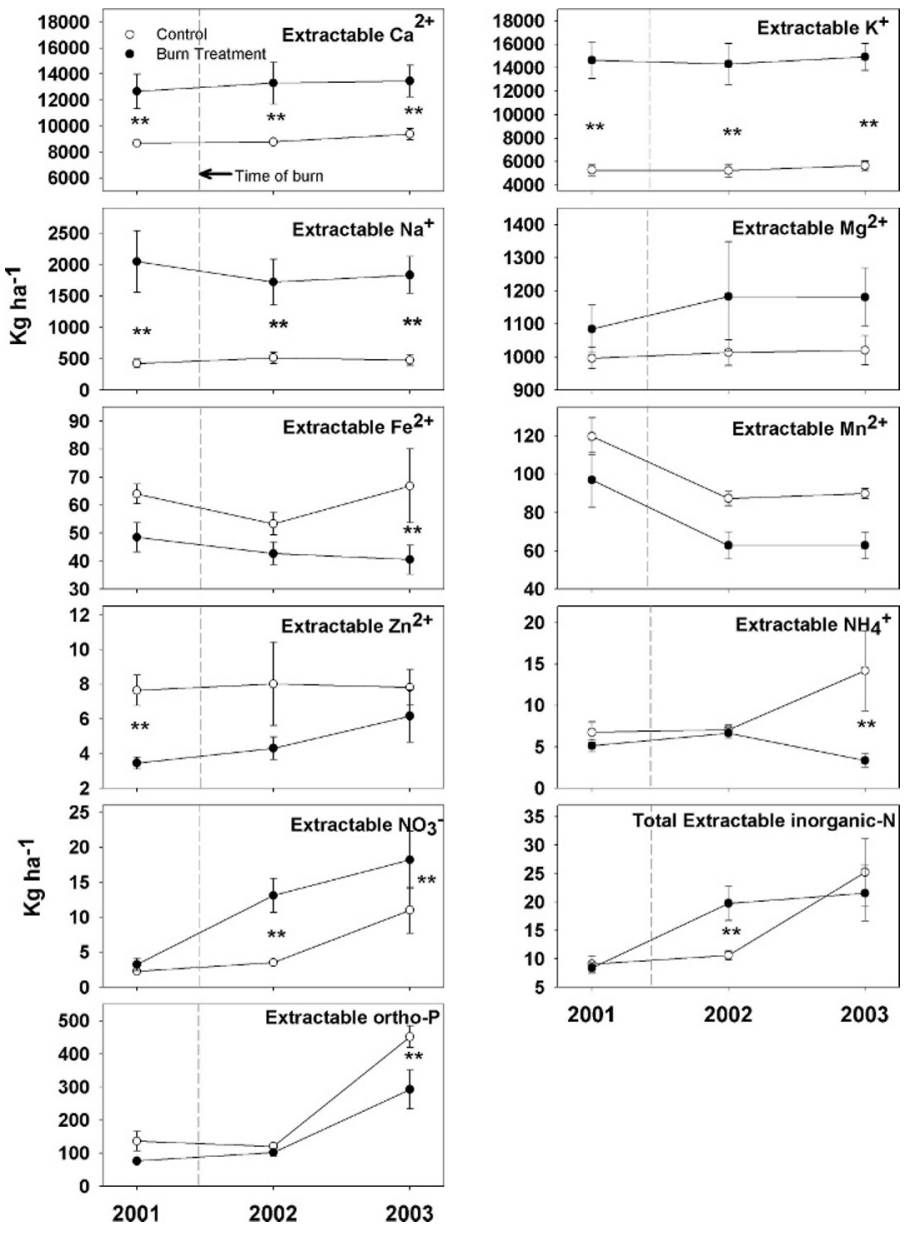

Figure 2. Mean extractable soil nutrient contents $\left(\mathrm{kg} \cdot \mathrm{ha}^{-1}\right)$ and standard errors in 2001, 2002, and 2003 for the soil profile $(8-52 \mathrm{~cm})$ at the control $(2195 \mathrm{~m})$ and burned $(2225 \mathrm{~m})$ sites. Asterisks indicate differences between sites.

was higher on the control site but only before the burn $(P<0.05$; Fig. 1). All other nutrients were similar on both sites before the burn (Fig. 1). Burning increased near-surface $\mathrm{NH}_{4}^{+}$, $\mathrm{NO}_{3}^{-}$, total inorganic $\mathrm{N}$, and $\mathrm{Ca}^{2+}(P<0.05$; Fig. 1). Burning also appears to have influenced levels of extractable surface soil $\mathrm{Mn}^{2+}$ and $\mathrm{Zn}^{2+}$. Prior to the burn, extractable $\mathrm{Zn}^{2+}$ was greater on the control site when compared to the burn site. However, following the burn (2002 and 2003), extractable $\mathrm{Zn}^{2+}$ on the burn site was similar to the control site, possibly indicating that burning increased extractable $\mathrm{Zn}^{2+}(P<0.05$; Fig. 1). A similar trend is evident for extractable $\mathrm{Mn}^{2+}$. Extractable $\mathrm{Mn}^{2+}$ was similar on control and burn plots before burning and in the first year postburn (2002). However, by 2003, extractable $\mathrm{Mn}^{2+}$ was higher on the burned site compared to the control $\left(P<0.05\right.$; Fig. 1). The nutrients $\mathrm{Mn}^{2+}, \mathrm{Zn}^{2+}, \mathrm{Mg}^{2+}, \mathrm{Na}^{+}$, and ortho-P differed by microsite, and contents were typically greater under trees and shrubs than in interspace microsites $(P<0.05$; Rau et al. 2007).

Trends for soil profile nutrients were almost identical to near-surface nutrients before treatment, and $\mathrm{Ca}^{2+}, \mathrm{K}^{+}$, and $\mathrm{Na}^{+}$ contents were higher on the burn site before and after burning (Fig. 2). Before the burn, $\mathrm{Zn}^{2+}$ was higher on the control site $(P<0.05)$. All other nutrients were similar on both sites before 

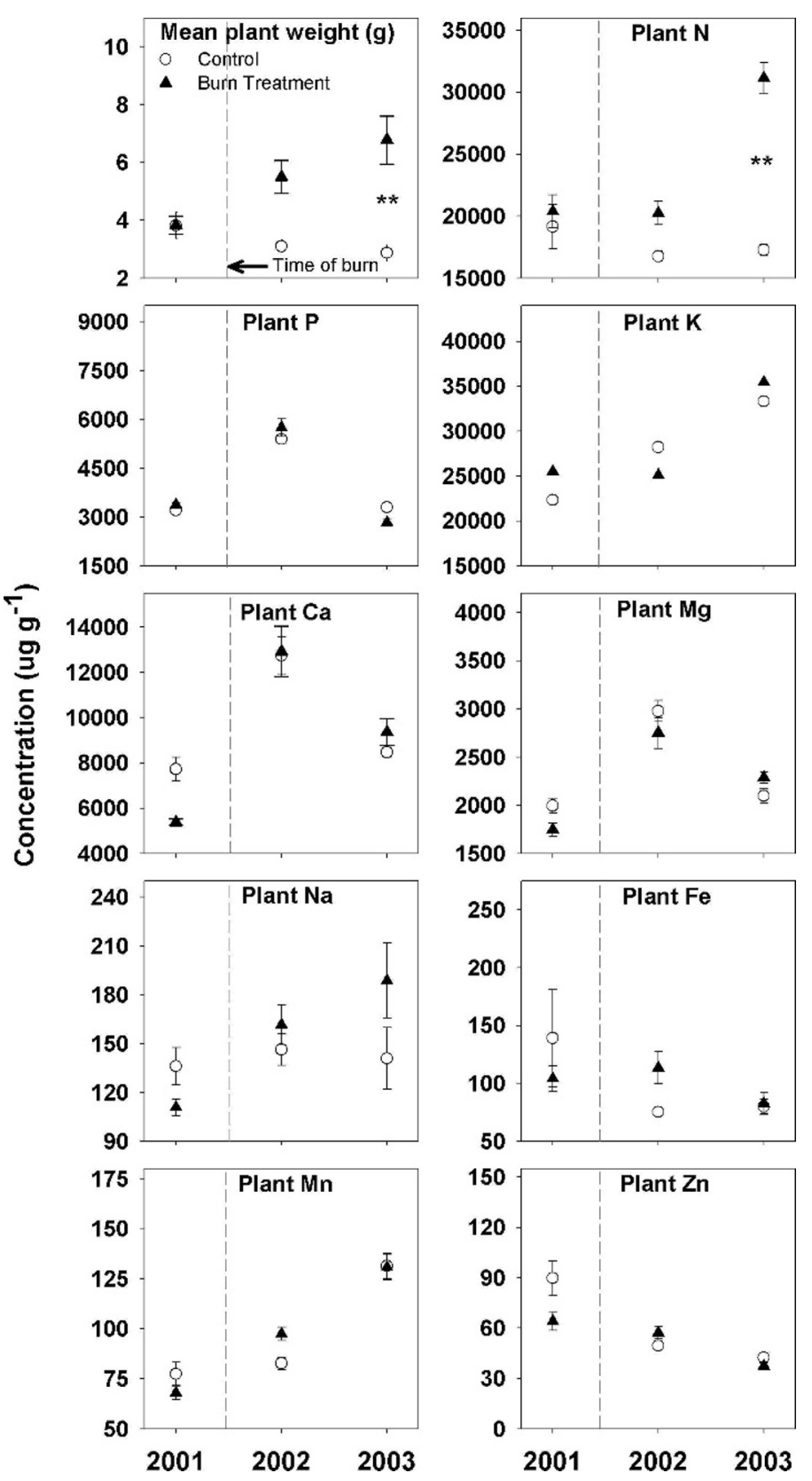

Figure 3. Mean aboveground plant weight $(\mathrm{g})$, tissue nutrient concentrations $\left(\mu \mathrm{g} \cdot \mathrm{g}^{-1}\right)$, and standard errors for Crepis acuminata in 2001, 2002, and 2003 on the control $(2195 \mathrm{~m})$ and burned $(2225 \mathrm{~m})$ sites. Asterisks indicate differences between sites.

the burn (Fig. 2). Burning had fewer effects on the soil profile than it did on near-surface soils with increases observed only for $\mathrm{NO}_{3}^{-}$and total inorganic $\mathrm{N}(P<0.05$; Fig. 2). The same trend identified for extractable surface $\mathrm{Zn}^{2+}$ is also identified for $\mathrm{Zn}^{2+}$ in the rest of the profile. Prior to the burn, extractable $\mathrm{Zn}^{2+}$ was greater on the control site when compared to the burn site. However, following the burn, extractable $\mathrm{Zn}^{2+}$ on the burn site was similar to the control site, possibly indicating that burning increased extracable $\mathrm{Zn}^{2+}(P<0.05$; Fig. 2). Soil profile nutrients that differed by microsite included $\mathrm{Mn}^{2+}, \mathrm{Fe}^{2+}$, $\mathrm{Zn}^{2+}, \mathrm{Ca}^{2+}, \mathrm{Mg}^{2+}, \mathrm{K}^{+}, \mathrm{NH}_{4}^{+}$, and total inorganic $\mathrm{N}(P<0.05)$.
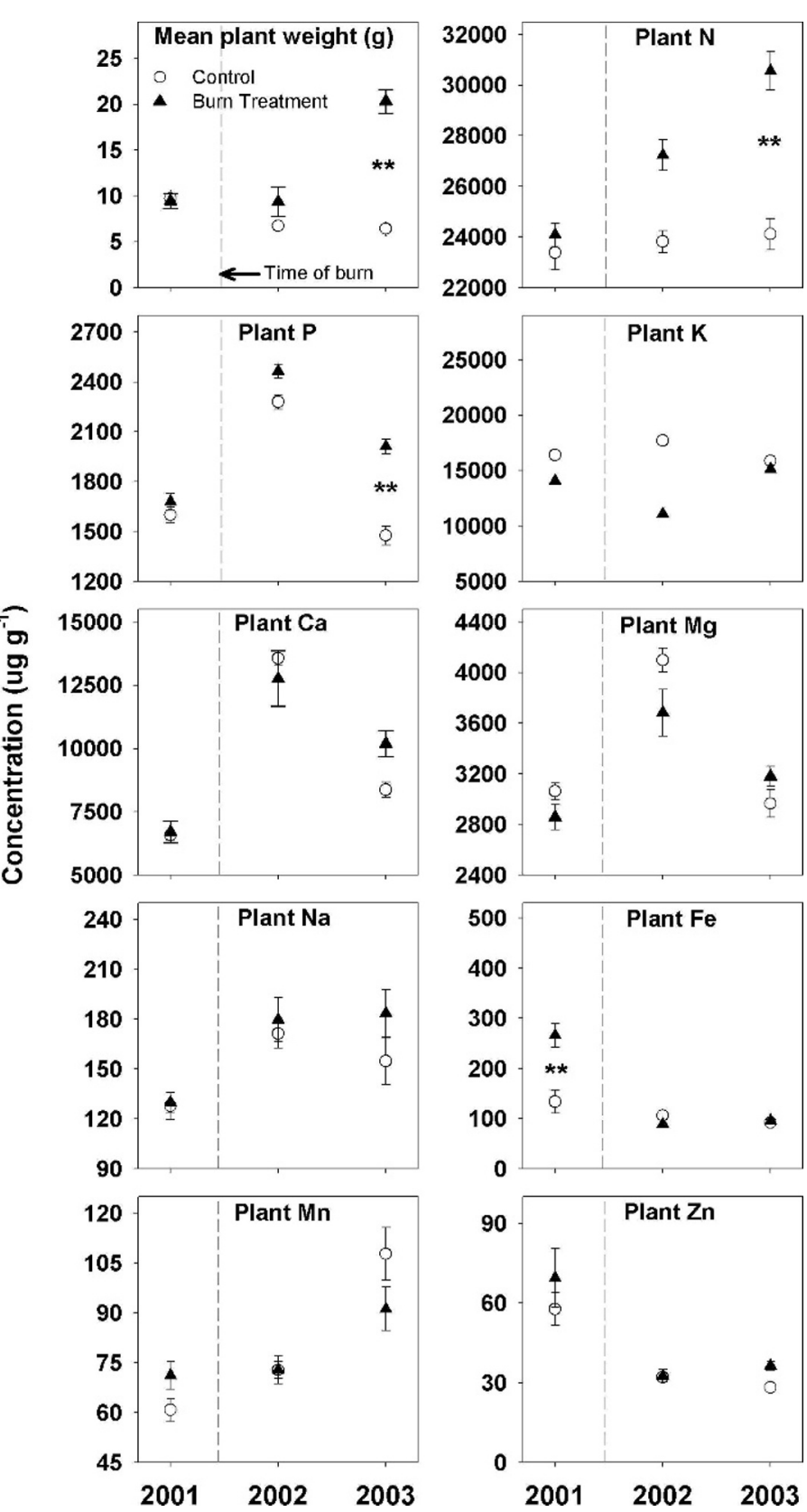

Figure 4. Mean aboveground plant weight $(g)$, tissue nutrient concentrations $\left(\mu \mathrm{g} \cdot \mathrm{g}^{-1}\right)$, and standard errors for Lupinus argenteus in 2001, 2002, and 2003 on the control (2195 m) and burned (2225 m) sites. Asterisks indicate differences between sites.

Again, nutrient contents were typically greater under trees and shrubs than in interspace microsites (Rau et al. 2007).

\section{Spatial, Temporal, and Burning Effects on Plants}

The analyses by individual species indicated that plants were similar on control and treatment sites before the burn and that burning had significant effects on all plant species. Burning increased plant weight and tissue $\mathrm{N}$ concentration in the forb C. acuminata by the second year following fire (Fig. 3). The forb, $L$. argenteus had increased plant weight, tissue $\mathrm{N}$, and $\mathrm{P}$ by the second year after burning. Also, L. argenteus $\mathrm{Fe}$ 

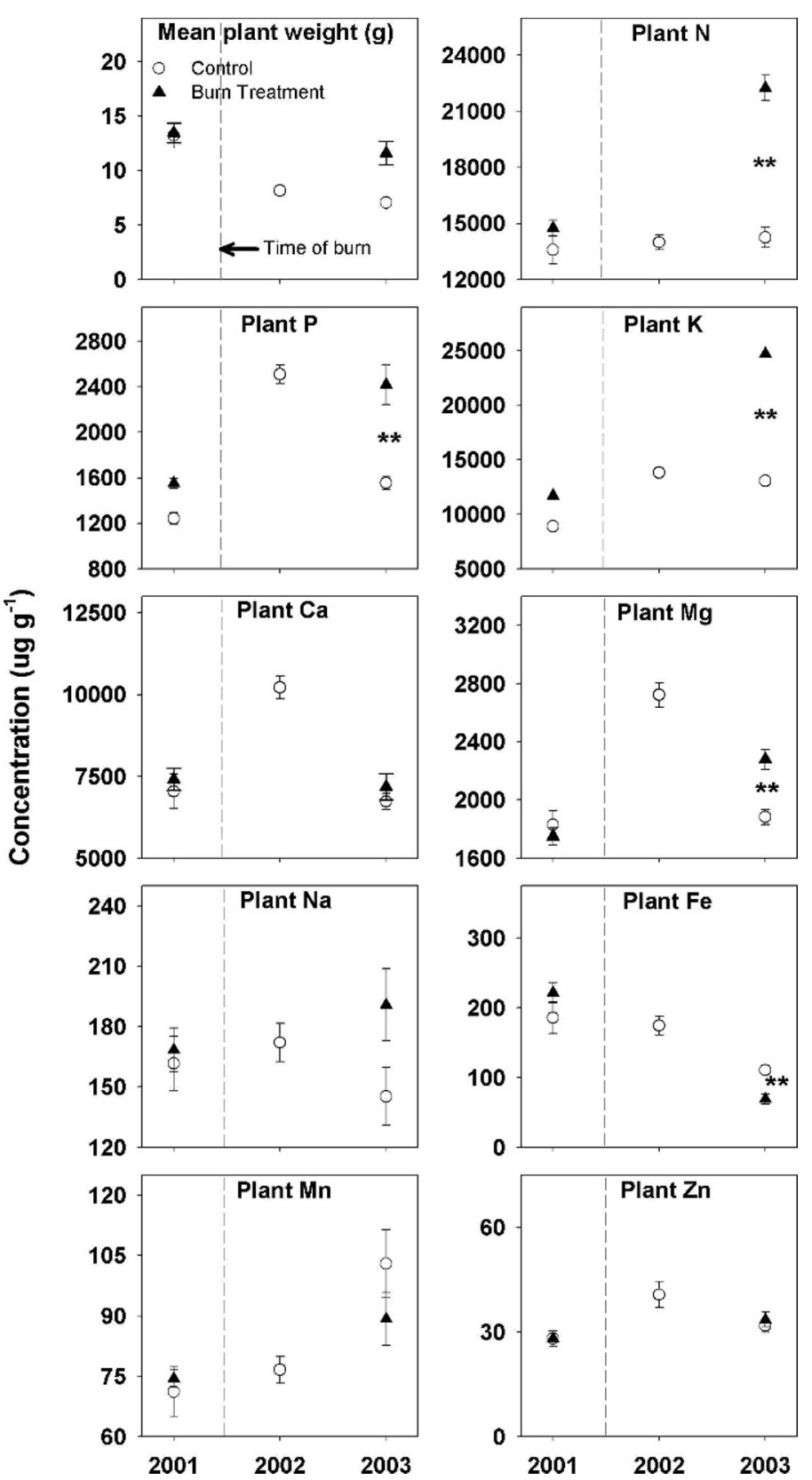

Figure 5. Mean aboveground plant weight $(\mathrm{g})$, tissue nutrient concentrations $\left(\mu \mathrm{g} \cdot \mathrm{g}^{-1}\right)$, and standard errors for Eriogonum umbellatum in 2001, 2002, and 2003 on the control (2195 m) and burned (2225 m) sites. Asterisks indicate differences between sites.

concentrations decreased in the first and second year after burning (Fig. 4). The woody forb Eriogonum umbellatum did not resprout in the first season following the spring prescribed burn on the burned site. However, by the next spring, the forb resprouted and by the next summer had higher tissue N, P, K, and $\mathrm{Mg}$ (but lower Fe) on the burned site (Fig. 5). Eriogonum elatum, a low growing fleshy forb, resprouted shortly after the prescribed fire on the burned site but had no initial nutritional response. By the second year after burning, plant weight and tissue $\mathrm{K}$ had increased on the burned site (Fig. 6). The perennial grass Poa secunda secunda was another species that did not resprout on the burned site in the first season following the

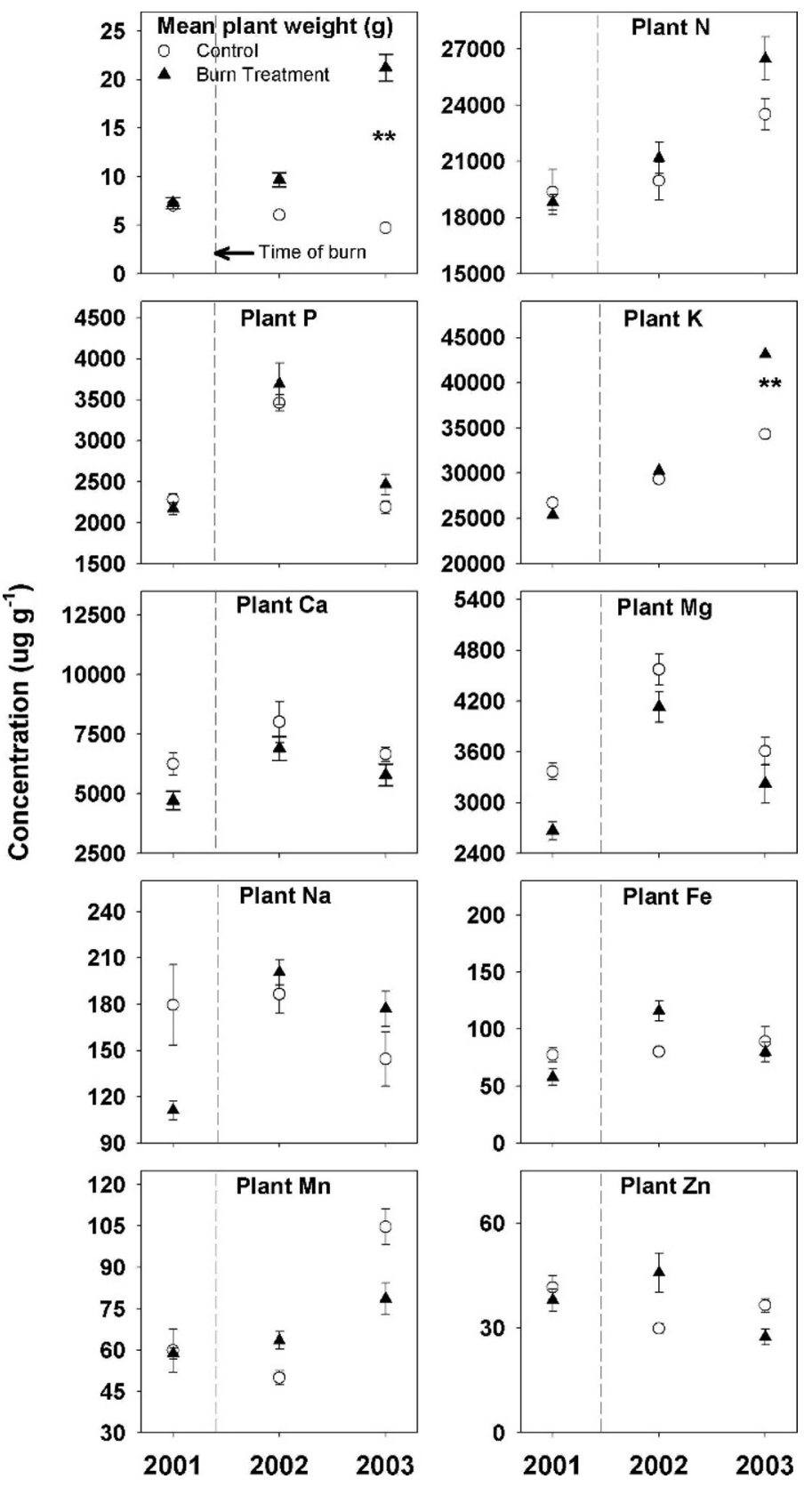

Figure 6. Mean aboveground plant weight $(\mathrm{g})$, tissue nutrient concentrations $\left(\mu \mathrm{g} \cdot \mathrm{g}^{-1}\right)$, and standard errors for Eriogonum elatum in 2001, 2002, and 2003 on the control $(2195 \mathrm{~m})$ and burned $(2225 \mathrm{~m})$ sites. Asterisks indicate differences between sites.

spring prescribed fire. However, by the second year following the prescribed fire, Poa secunda secunda resprouted and had increased plant weight and tissue $\mathrm{N}$ and $\mathrm{Mg}$ as a result of burning (Fig. 7). F. idahoensis, another perennial grass, did resprout the first season after the fire and had immediate increases in tissue $\mathrm{N}$ and $\mathrm{P}$ (Fig. 8). In the second year after burning, F. idahoensis still had increased tissue $\mathrm{N}$ and also had increased tissue $\mathrm{K}, \mathrm{Ca}$, and $\mathrm{Mg}$ (Fig. 8). Tissue $\mathrm{Mn}$ had decreased in the second year on the burned site (Fig. 8).

F. idahoensis was the only species with significant microsite effects and microsite $\times$ burning interactions. Individual $F$. idahoensis plants were typically larger under tree and shrub 

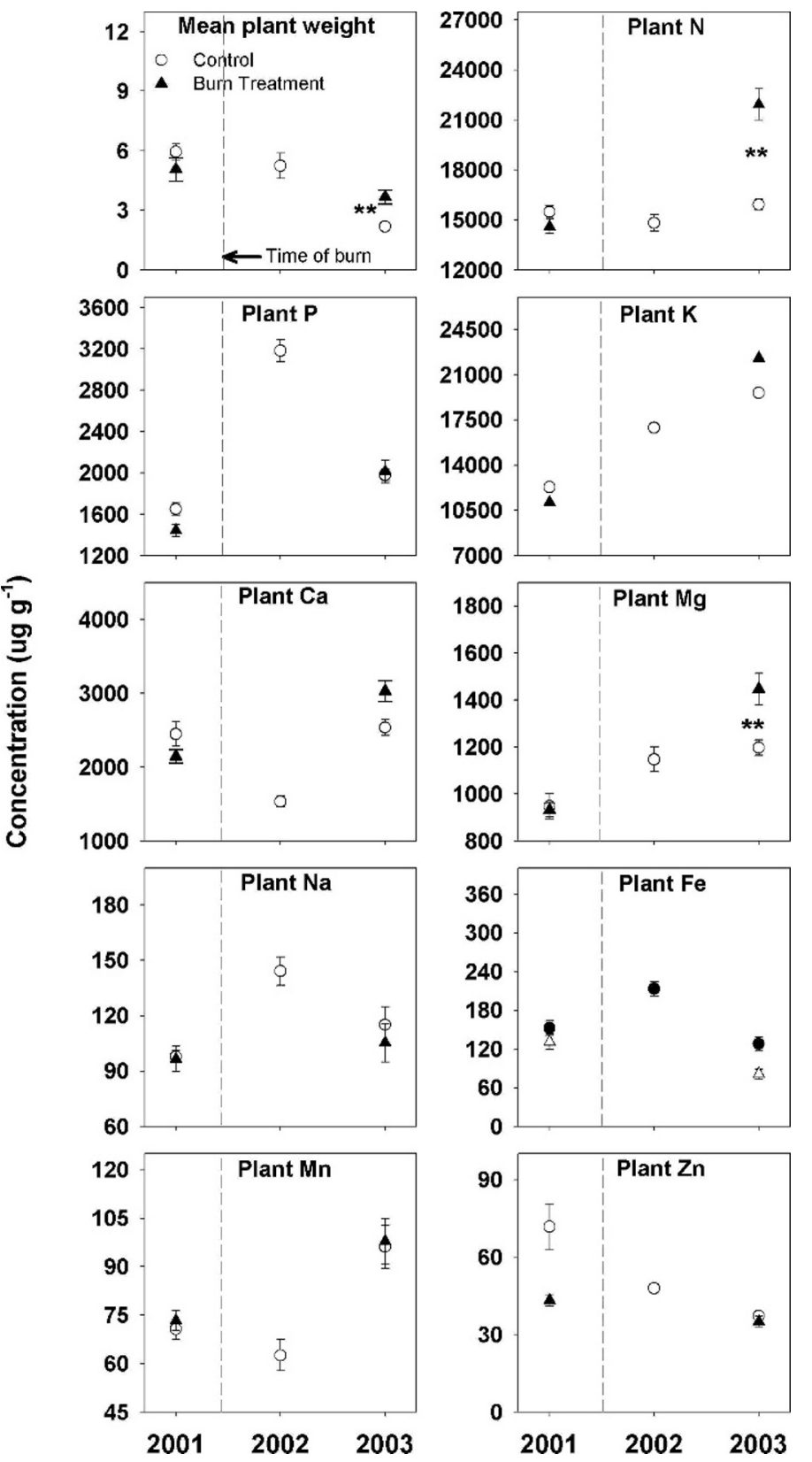

Figure 7. Mean aboveground plant weight (g), tissue nutrient concentrations $\left(\mu \mathrm{g} \cdot \mathrm{g}^{-1}\right)$, and standard errors for Poa secunda in 2001, 2002, and 2003 on the control (2195 m) and burned (2225 m) sites. Asterisks indicate differences between sites.

canopies before burning, but plant weights were similar among microsites after burning $(P<0.05)$. Also, plant tissue $\mathrm{Na}$ decreased in under tree and interspace microsites but increased in undershrub canopy microsites by the second season after burning as indicated by mean comparisons of the year $\times$ site $\times$ microsite interaction $(P<0.05)$.

\section{Soil Relationship to Plants}

Although plants differed in their relative nutrient concentrations, there were common trends in response to burning. Therefore, to simplify the results and discussion of the canonical correspondence analysis (CCA), we limited the plant
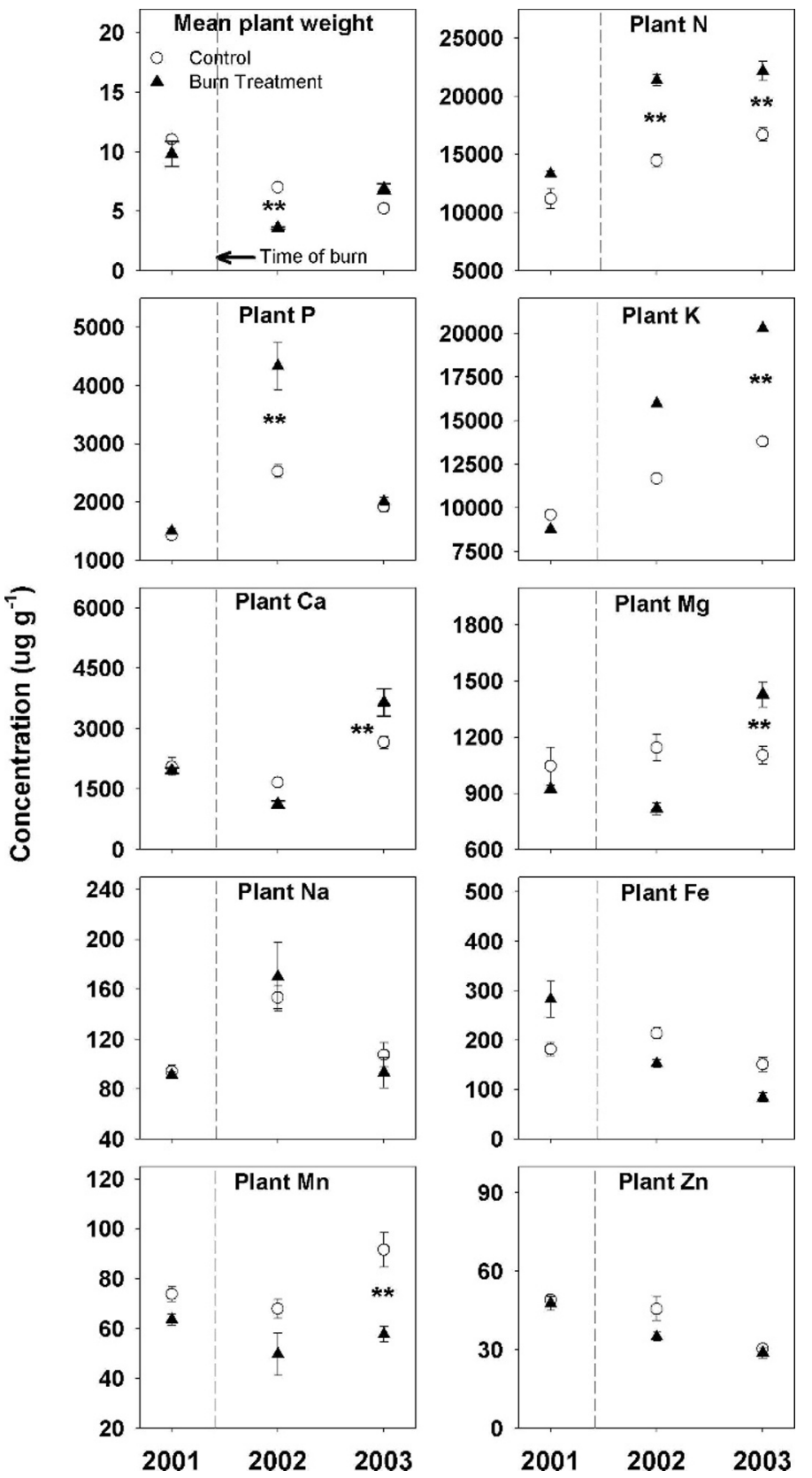

Figure 8. Mean aboveground plant weight $(\mathrm{g})$, tissue nutrient concentrations $\left(\mu \mathrm{g} \cdot \mathrm{g}^{-1}\right)$, and standard errors for Festuca idahoensis in 2001, 2002, and 2003 on the control (2195 m) and burned (2225 m) sites. Asterisks indicate differences between sites.

response variables to those most commonly affected by burning, that is, plant weight and tissue $\mathrm{N}, \mathrm{P}, \mathrm{K}$, and $\mathrm{Mg}$ (Fig. 9). This allowed us to include all plant species in the same CCA. Results from the CCA indicate there are three significant eigenvalues in the data set (Table 1). The first axis indicates positive relationships among all the plant variables, which commonly responded to burning and the binary variable "treatment," soil surface $\mathrm{K}^{+}, \mathrm{NO}_{3}^{-}$, and inorganic $\mathrm{N}$ (Table 2). The second axis indicates moderate positive association between plant tissue $\mathrm{Mg}$ and soil surface $\mathrm{Mn}^{2+}, \mathrm{Ca}^{2+}$, and $\mathrm{Mg}^{2+}$ (Table 2). There also is a moderate negative association between plant $\mathrm{Mg}$ and soil surface ortho-P and soil profile 


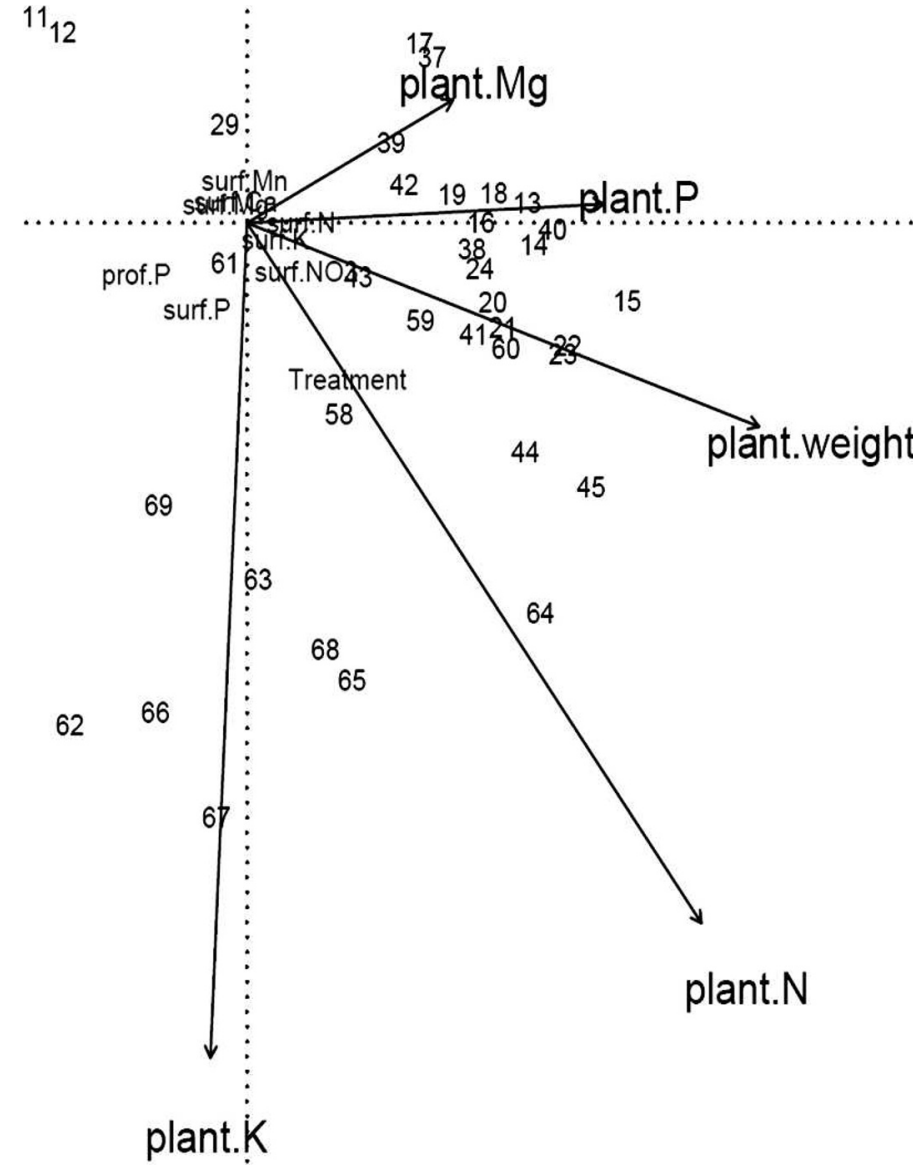

Figure 9. Canonical correspondence analysis ordination diagram with observation numbers, relevant soil nutrients and treatments, and relevant plant nutrients and weight (arrows). The first axis is horizontal (soil nutrients and treatment), and the second axis is vertical (plant nutrients and weight). Observations far from the origin are not shown so that more detail can be seen on this figure.

ortho-P (Table 2). The third axis uniquely relates plant weight with soil surface $\mathrm{Mn}^{2+}$ (Table 2).

\section{DISCUSSION}

\section{Spatial, Temporal, and Burning Effects on Soils}

Burning resulted in increases in soil surface $\mathrm{NH}_{4}^{+}, \mathrm{NO}_{3}^{-}$, and total inorganic $\mathrm{N}$ as observed in other semiarid systems (Hobbs and Schimel 1984; DeBano and Klopatek 1988; Covington et al. 1991; Blank and Zamudio 1998). The increases in $\mathrm{NO}_{3}^{-}$and inorganic $\mathrm{N}$ occurred throughout the entire soil profile. Release of $\mathrm{NH}_{4}^{+}$from organic matter occurs during burning and decomposition of incompletely consumed above- and belowground biomass, and then $\mathrm{NH}_{4}^{+}$is converted to $\mathrm{NO}_{3}^{-}$by soil microorganisms (Covington et al. 1991). The $\mathrm{NO}_{3}^{-}$ion is highly mobile and easily moves down through the soil profile (Chorover et al. 1994). The observed increases in the mineral cations $\mathrm{Ca}^{2+}$, $\mathrm{Mn}^{2+}$, and $\mathrm{Zn}^{2+}$ likely were due to deposition of ash onto the soil surface after combustion and incorporation into the mineral soil (Neary et al. 1999). Micronutrients are seldom sampled following fire, and the increases in $\mathrm{Mn}^{2+}$ and $\mathrm{Zn}^{2+}$ rarely have been documented (Neary et al. 1999). Differences in nutrient contents among microsites can be attributed to variations in plant uptake, litter fall, and microbial communities (Chambers 2001; Compton and Boone 2002; Booth et al. 2003; Rau et al. 2007). These differences often persist following fire (Blank et al. 1994a; Blank and Zamudio 1998; Rau et al. 2007).

\section{Spatial, Temporal, and Burning Effects on Plants}

The effect of microsite on aboveground plant characteristics was minimal in this study. Although soil nutrients differed statistically by microsite, the absolute magnitude of that difference may not be large enough to affect plant nutrient uptake (Rau et al. 2007). More investigation may be necessary to determine the interactions between nutrient availability and plant physiological parameters at the microsite scale.

Burning had a significant effect on all the plant species studied, and this effect increased over time. For plants that resprouted the first season after the burn (June 2002), there were few differences in aboveground plant biomass or nutrients on control vs. burned sites. Only F. idahoensis had higher plant $\mathrm{N}$ and $\mathrm{P}$ concentrations the first season after burning, and $L$. argenteus had decreased $\mathrm{Fe}$ on the burn site the first season after the burn (June 2002). Increases in plant nutrients have been reported in the first growing season following spring burns in more mesic environments (Cook et al. 1994; Anderson and Menges 1997; Bennett et al. 2002). The general lack of response during the first growing season in this semiarid environment likely occurred because of the short growing season and a delayed increase in soil nutrient availability within the rooting zone. Although increases in $\mathrm{NH}_{4}^{+}$were observed in the $0-3-\mathrm{cm}$ depth immediately after the burn, increases in $\mathrm{NO}_{3}^{-}$and in total inorganic $\mathrm{N}$ were not seen in the soil profile until the first fall after the burn (Rau et al. 2007). The increased nutrient response of $F$. idahoensis to burning in the first season may be because of lower aboveground biomass on the burned location (Fig. 8). Smaller and younger plants have been documented to have higher aboveground concentrations of mineral nutrients because of the low percentage of structural tissues in smaller younger plants (Schaffers 2002). By the second year after burning, increases in plant biomass and nutrient concentrations were evident for all species. Soil content of $\mathrm{NH}_{4}^{+}, \mathrm{NO}_{3}^{-}$, and total inorganic $\mathrm{N}$ were all higher on the burned than control site by the first year after the burn at the $0-3-\mathrm{cm}$ depth, and $\mathrm{NO}_{3}^{-}$and total inorganic $\mathrm{N}$ were elevated in the soil profile.

Some variation in individual species responses to burning were observed and are likely due to differences in burn tolerance, root characteristics, mycorrhizal associations, and ecophysiological characteristics (Steuter and McPherson 1995; Anderson and Menges 1997). Species dependent responses to burning have been documented elsewhere (Cook et al. 1994; Anderson and Menges 1997). In this study, two of the plant species, Eriogonum umbellatum and Poa secunda secunda, did not resprout the first summer after the spring prescribed burn. Eriogonum umbellatum is a large woody forb with extensive belowground biomass allocation. A larger fuel component at the time of burning may have increased temperatures at the root crown and delayed vegetative recovery (Steuter and McPherson 1997). Poa secunda secunda is a cool-season grass and likely did not resprout in the first year because conditions were not favorable in the weeks following the burn. 
Table 1. Eigenvalues, correlation coefficients, proportion of variance, and $P$ values for the canonical correspondence analysis of soil and plant nutrient data. Results for axes 1 through 3 are shown.

\begin{tabular}{lrrr}
\hline & \multicolumn{3}{c}{ Axis } \\
\cline { 2 - 4 } & \multicolumn{1}{c}{1} & \multicolumn{1}{c}{2} & \multicolumn{1}{c}{3} \\
\hline Eigenvalues & 7.2748 & 2.1643 & 0.8739 \\
Correlation coefficients & 0.9376 & 0.8270 & 0.7422 \\
Proportion of variance & 0.6214 & 0.1849 & 0.1048 \\
$P$ value & $<0.0001$ & $<0.0001$ & 0.0091 \\
\hline
\end{tabular}

\section{Soil Relationship to Plants}

Although each plant species in our study had variable responses to fire, most of the species exhibited an increase in plant weight in response to burning (C. acuminata, L. argenteus, Eriogonum elatum, and Poa secunda secunda) and in tissue N concentrations (C. acuminata, L. argenteus, Eriogonum umbellatum, Poa secunda secunda, and F. idaboensis). In our study, plant weight and tissue $\mathrm{N}$ were most closely related to the blanket variable "treatment," soil surface $\mathrm{NO}_{3}^{-}$, total inorganic $\mathrm{N}$, and $\mathrm{K}^{+}$concentrations. Other observed responses to burning, including increased tissue $\mathrm{Mg}$ (Eriogonum umbellatum, Poa secunda secunda, and F. idahoensis), increased tissue $\mathrm{K}$ (Eriogonum umbellatum, Eriogonum elatum, and F. idaboensis), and increased tissue P (L. argenteus, Eriogonum umbellatum, and F. idaboensis), also were most closely related to "treatment," surface $\mathrm{NO}_{3}^{-}$, inorganic $\mathrm{N}$, and $\mathrm{K}^{+}$. The canonical soil variable "treatment" comprises a complex set of variables not measured in this study. It could be argued the influence of treatment resulted from reduced competition and increased available soil moisture due to reduction of woody biomass following burning. Removal of woody biomass has been shown to increase soil moisture and herbaceous vegetation in arid rangelands (Chambers and Linerooth 2001; Wright and Chambers 2002). Sturgis (1993) documented that herbaceous biomass doubled the first three years following shrub removal and that effects of shrub removal were evident 20 years

Table 2. Canonical coefficients and intraset correlations for the plant and soil variables from the canonical correspondence analysis. Results for axes 1 through 3 are shown.

\begin{tabular}{|c|c|c|c|c|c|c|}
\hline \multirow[b]{2}{*}{ Axis variable } & \multicolumn{3}{|c|}{ Canonical coefficients } & \multicolumn{3}{|c|}{ Correlation coefficients } \\
\hline & 1 & 2 & 3 & 1 & 2 & 3 \\
\hline \multicolumn{7}{|l|}{ Plant } \\
\hline Weight & 0.497 & 0.288 & 0.800 & 0.466 & 0.238 & 0.594 \\
\hline Tissue $\mathrm{Mg}$ & 0.528 & 0.517 & -0.570 & 0.495 & 0.427 & -0.423 \\
\hline Tissue $\mathrm{K}$ & 0.731 & -0.480 & -0.253 & 0.686 & -0.397 & -0.188 \\
\hline Tissue $\mathrm{P}$ & 0.554 & 0.289 & -0.621 & 0.520 & 0.239 & -0.461 \\
\hline Tissue $\mathrm{N}$ & 0.826 & -0.183 & -0.008 & 0.774 & -0.151 & -0.006 \\
\hline \multicolumn{7}{|l|}{ Soil } \\
\hline Treatment & 0.941 & -0.024 & 0.035 & 0.882 & -0.020 & 0.026 \\
\hline Surface $\mathrm{Mn}^{2+}$ & 0.137 & 0.423 & 0.663 & 0.129 & 0.350 & 0.492 \\
\hline Surface $\mathrm{Fe}^{2+}$ & 0.014 & 0.399 & 0.389 & 0.013 & 0.330 & 0.289 \\
\hline Surface $\mathrm{Zn}^{2+}$ & 0.303 & 0.318 & 0.159 & 0.284 & 0.263 & 0.118 \\
\hline Surface $\mathrm{Ca}^{2+}$ & 0.330 & 0.427 & 0.404 & 0.309 & 0.353 & 0.300 \\
\hline Surface $\mathrm{Mg}^{2+}$ & 0.476 & 0.427 & 0.190 & 0.446 & 0.353 & 0.141 \\
\hline Surface $\mathrm{K}^{+}$ & 0.577 & 0.177 & 0.382 & 0.541 & 0.147 & 0.284 \\
\hline Surface $\mathrm{Na}^{+}$ & 0.352 & 0.045 & 0.267 & 0.330 & 0.037 & 0.198 \\
\hline Surface ortho-P & 0.432 & -0.436 & 0.207 & 0.405 & -0.360 & 0.154 \\
\hline Surface $\mathrm{NH}_{4}^{+}$ & 0.354 & 0.397 & 0.258 & 0.332 & 0.328 & 0.192 \\
\hline Surface $\mathrm{NO}_{3}^{-}$ & 0.738 & 0.192 & 0.298 & 0.692 & 0.159 & 0.221 \\
\hline Surface inorganic N & 0.568 & 0.361 & 0.309 & 0.532 & 0.298 & 0.230 \\
\hline Profile $\mathrm{Mn}^{2+}$ & -0.312 & 0.399 & 0.432 & -0.293 & 0.330 & 0.320 \\
\hline Profile $\mathrm{Fe}^{2+}$ & -0.233 & 0.329 & 0.284 & -0.218 & 0.272 & 0.211 \\
\hline Profile $\mathrm{Zn}^{2+}$ & -0.073 & 0.153 & 0.038 & -0.068 & 0.127 & 0.028 \\
\hline Profile $\mathrm{Ca}^{2+}$ & 0.319 & 0.398 & 0.346 & 0.299 & 0.329 & 0.257 \\
\hline Profile $\mathrm{Mg}^{2+}$ & 0.225 & 0.367 & 0.239 & 0.211 & 0.303 & 0.177 \\
\hline Profile $\mathrm{K}^{+}$ & 0.477 & 0.241 & 0.396 & 0.447 & 0.199 & 0.294 \\
\hline Profile $\mathrm{Na}^{+}$ & 0.425 & 0.150 & 0.344 & 0.399 & 0.124 & 0.256 \\
\hline Profile ortho-P & -0.024 & -0.514 & 0.072 & -0.023 & -0.425 & 0.054 \\
\hline Profile $\mathrm{NH}_{4}^{+}$ & -0.143 & 0.146 & -0.028 & -0.134 & 0.121 & -0.021 \\
\hline Profile $\mathrm{NO}_{3}^{-}$ & 0.334 & 0.063 & 0.014 & 0.313 & 0.052 & 0.011 \\
\hline Profile inorganic N & 0.138 & 0.133 & -0.008 & 0.129 & 0.110 & -0.006 \\
\hline
\end{tabular}


following treatment. Similarly, increasing near-surface-soil N has been documented to increase plant weight and $\mathrm{N}$ content in agricultural studies (Marschner 1995). Nitrogen is typically limiting in most systems, and plants increase uptake, have a higher photosynthetic rate, and grow larger when nitrogen availability is increased (Marschner 1995). The relationship between plant weight, plant tissue nutrients, and soil surface $\mathrm{K}^{+}$ may be confounded by the fact that the burn site initially had higher $\mathrm{K}^{+}$than the control site.

The relationships among fire-induced increases in plant tissue $\mathrm{Mg}, \mathrm{P}$, and $\mathrm{K}$ and soil properties are not well understood, and the timing of plant and soil collections in this study may make the interpretation of these results more complex. However, it is possible that increases in plant $\mathrm{Mg}, \mathrm{P}$, and $\mathrm{K}$ are directly and indirectly related to reduced competition, increased soil inorganic N, and soil cations. Plant uptake of cations has been positively and directly correlated with the concentration of the corresponding cation in soil (Schaffers 2002). Also, it has been observed that cation concentrations in soil do not necessarily affect plant uptake of the corresponding cation but rather influence the uptake of a different nutrient (Hayati and Proctor 1990). It also is possible that increases in plant tissue $\mathrm{P}$ and cations are necessary to balance increases in plant tissue $\mathrm{N}$ (Marschner 1995). Thus, these relationships may be a result of simultaneous and complex nutrient limitation in native soils (Hayati and Proctor 1990).

\section{IMPLICATIONS}

Plant nutritional response to fire has been documented by several authors, yet few attempts have been made to quantify the direct influence of wildland soil chemical changes on plant nutrition (Carreira and Niell 1992; Blank et al. 1994b; Cook et al. 1994; Anderson and Menges 1997; Bennett et al. 2002). Results from our study indicate that fire increased soil nitrogen and metal cations immediately following fire and for at least one year postburn. Vegetation that resprouted or germinated on burned locations responded not only to changes in soil nutrients but also to possible changes in plant competition, soil water content, organic compounds, and microbial communities (Carreira and Niell 1992; Blank et al. 1994b; Cook et al. 1994; Anderson and Menges 1997; Bennett et al. 2002).

The direct influence of soil nutrients on plant nutrition in wild systems is not well understood but appears to be species specific. Previous studies have found that soil nutrient supply or content has direct positive or negative relationships with plant tissue concentrations of that nutrient or other related nutrients (Hayati and Proctor 1990; Schaffers 2002). In our system, the effects of burning and changes in soil surface $\mathrm{NO}_{3}^{-}$and inorganic $\mathrm{N}$ concentrations as measured in the fall had dramatic influences on plant weight and tissue $\mathrm{N}$ concentrations. Plants in our study responded better to changes that affected the soil surface because of the immediate and persistent increase in soil nutrients.

It appears that spring prescribed burning was a plausible option for slowing pinyon-juniper expansion on our demonstration area and may be applicable to other areas as long as sufficient understory vegetation is present on locations to be treated (Chambers et al. 2007). Spring burning increased understory plant biomass or nutrient concentration for all species in our study. Fall burning in these woodlands may not have the same beneficial effects because of decreased soil and fuel moisture and increased fire severity (Cook et al. 1994).

\section{ACKNOWLEDGMENTS}

We thank David Board and Dave Turner for assistance with the statistical design.

\section{LITERATURE CITED}

Anderson, R. C., And E. S. Menges. 1997. Effects of fire on sandhill herbs: nutrients, mycorrhizae, and biomass allocation. American Journal of Botany 84(8):938-948.

Barnett, J. K., and J. A. Crawford. 1994. Pre-laying nutrition of sage grouse hens in Oregon. Journal of Range Management 47(2):114-118.

Bennett, L. T., T. S. Judd, And M. A. Adams. 2002. Growth and elemental content of perennial grasslands following burning in semi-arid, sub-tropical Australia. Plant Ecology 164:185-199.

Blank, R. R., F. Allen, and J. A. Young. 1994a. Extractable anions in soils following wildfire in a sagebrush-grass community. Soil Science Society of America Journal 58:564-570.

Blank, R. R., F. Allen, and J. A. Young. 1994b. Growth and elemental content of several sagebrush-steppe species in unburned and post-wildfire soil and plant effects on soil attributes. Plant and Soil 164:35-41.

Blank, R. R., F. Allen, and J. A. Young. 1996. Influence of simulated burning of soillitter from low sagebrush, squirreltail, cheatgrass, and medusahead on watersoluble anions and cations. International Journal Wildland Fire 6(3):137-143.

Blank, R. R., and D. C. Zamudio. 1998. The influence of wildfire on aqueousextractable soil solutes in forested and wet meadow ecosystems along the eastern Sierra-Nevada range, California. International Journal of Wildland Fire 8(2):79-85

Bоoth, M. S., M. M. Caldwell, and J. M. Stark. 2003. Overlapping resource use in three Great Basin species: implications for community invasibility and vegetation dynamics. Journal of Ecology 91:36-48.

Carreira, J. A., and F. X. Niell. 1992. Plant changes in a semi-arid Mediterranean shrubland after fire. Journal of Vegetation Science 3:457-466.

CertinI, G. 2005. Effects of fire on properties of forest soil: a review. Oecologia 143:1-10.

Chambers, J. C. 2001. Pinus monophylla establishment in an expanding PinusJuniperus woodland: environmental conditions, facilitation and interacting factors. Journal of Vegetation Science 12:27-40.

Chambers, J. C., and A. R. Linnerooth. 2001. Restoring sagebrush dominated riparian corridors using alternative state and threshold concepts: environmental and seedling establishment response. Applied Vegetation Science 4:157-166.

Chambers, J. C., B. A. Roundy, R. R. Blank, S. E. Meyer, and A. Whittaker. 2007. What makes great basin sagebrush ecosystems invasible by Bromus tectorum? Ecological Monographs 77:117-145.

Chorover, J., P. M. Vitousek, D. A. Everson, A. M. Esperanza, and D. Turner. 1994. Solution chemistry profiles of mixed-conifer forests before and after fire. Biogeochemistry 26:115-144.

Compton, J. E., AND R. E. Boone. 2002. Soil nitrogen transformations and the role of light fraction organic matter in forest soils. Soil Biology and Biochemistry 34:933-943

Connelly, J. W., S. T. Knick, M. A. Schroeder, and S. J. Stiver. 2004. Conservation assessment of greater sage-grouse and sagebrush habitats. Cheyenne, WY, USA: Western Association of Fish and Wildlife Agencies. Unpublished report. $20 \mathrm{p}$.

Cook, J. G., T. J. HeRSheY, And L. L. Irwin. 1994. Vegetative response to burning on Wyoming mountain-shrub big game ranges. Journal of Range Management 47:296-302. 
Covington, W. W., and L. F. DeBano. 1988. Effects of fire on pinyon-juniper soils. Panel paper presented at the Effects of Fire in Management of Southwestern Natural Resources conference; 14-17 November 1988; Tucson, AZ, USA. 8 p.

Covington, W. W., L. F. DeBano, and T. G. Huntsberger. 1991. Soil nitrogen changes associated with slash pile burning in pinyon-juniper woodlands. Forest Science 37:347-355.

DeBano, L. F., and J. M. Klopatek. 1988. Phosphorus dynamics of pinyon-juniper soils following simulated burning. Soil Science Society of America Journal 52:271-277.

Drut, M. S., W. H. Pyle, and J. A. Crawford. 1994. Diets and food selection of sage grouse chicks in Oregon. Journal of Range Management 47:90-93.

Fischer, R. A., K. P. ReESE, And J. W. Connelly. 1996. Influence of vegetal moisture content and nest fate on timing of female sage grouse migration. Condor 98:868-872.

GrueLL, G. E. 1999. Historical and modern roles of fire in pinyon-juniper. In: S. B. Monsen and R. Stevens [comps.]. Proceedings: ecology and management of pinyon-juniper communities in the interior west. Proceedings RMRS-P-9. Ogden, UT: US Department of Agriculture Forest Service Rocky Mountain Research Station. p. 24-28.

Hainds, M. J., R. J. Mitchell, B. J. Palik, L. R. Boring, and D. H. GJerstad. 1999. Distribution of native legumes (legumioseae) in frequently burned longleaf pine (pinaceae)-wiregrass (Poaceae) ecosystems. American Journal of Botany 86(11):1606-1614.

Hayati, A. A., and M. C. F. Proctor. 1990. Plant distribution in relation to mineral nutrient availability and uptake on a wet-heath site in south-west England. Journal of Ecology 78:134-151.

HendRicks, J. J., AND L. R. Boring. 1999. $\mathrm{N}_{2}$-fixation by native herbaceous legumes in burned pine ecosystems of the southeastern United States. Forest Ecology and Management 113:167-177.

HobBs, N. T., AND D. S. Schimel. 1984. Fire effects on nitrogen mineralization and fixation in mountain shrub and grassland communities. Journal of Range Management 37(5):402-404.

Horneck, D. A., And R. O. Miller. 1998. Determination of total nitrogen in plant tissue. In:Y. P. Karla [ED.]. Handbook of reference methods for plant analyses. Boca Raton, FL, USA: CRC Press. p. 75-83.

KeEney, D. R., AND D. W. Nelson. 1982. Nitrogen-inorganic forms. Methods of soil analyses, part 2. In: Chemical and microbiological properties. Agronomy Monograph no. 9. 2nd ed. Madison, Wl: Soil Science Society of America. p. 645-649.

Lindsay, W. L., ANd W. A. Norvell. 1978. Development of a DTPA soil test for zinc, iron, manganese, and copper. Soil Science Society of America Journal 42:421-428.

Marschner H. 1995. Mineral nutrition of higher plants. 2nd ed. San Diego, CA, USA: Academic Press. 889 p.

MILleR, R. F., AND J. A. Rose. 1999. Fire history and western juniper encroachment in sagebrush steppe. Journal of Range Management 52:550-559.
Miller, R. F., and R. J. Tausch. 2001. The role of fire in juniper and pinyon woodlands: a descriptive analysis. In: K. E. M. Gallet and T. P. Wilson [EDs.]. Proceedings of the Invasive Species Workshop: the role of fire in the control and spread of invasive species. Tallahassee, FL, USA: Tall Timbers Research Station. Miscellaneous Publication No. 11. p. 15-30.

Miller, R. F., and P. E. Wigand. 1994. Holocene changes in semi arid pinyonjuniper woodlands: response to climate, fire, and human activities in the U.S. Great Basin. Bioscience 44:465-474.

MıLleR, R. 0. 1998. High-temperature oxidation: dry ashing. In: Y. P. Karla [ED.]. Handbook of reference methods for plant analyses. Boca Raton, FL, USA: CRC Press. p. 53-56.

Neary, D. G., C. C. Klopatek, L. F. DeBano, and P. F. Ffolliot. 1999. Fire effects on below ground sustainability: a review and synthesis. Forest Ecology and Management 122:51-71.

OLSEn, S. R., And L. E. Sommers. 1982. Phosphorus. Methods of soil analyses, part 2. In: Chemical and microbiological properties. Agronomy Monograph no. 9. 2nd ed. Madison, WI: Soil Science Society of America. p. 421-422.

Rau, B. M., R. R. Blank, J. C. Chambers, and D. W. Johnson. 2007. Prescribed fire and time: Soil extractable nitrogen and phosphorus dynamics in a Great Basin sagebrush ecosystem. Journal of Arid Environments 71:362-375.

Rau, B. M., J. C. Chambers, R. R. Blank, and W. W. Miller. 2005. Hydrologic response of a central Nevada pinyon-juniper woodland to prescribed fire. Rangeland Ecology and Management 56:614-622.

ReIneR, A. L. 2004. Fuel load and understory community changes associated with varying elevation and pinyon-juniper dominance [master's thesis]. Reno, NV, USA: University of Nevada Reno. 63 p.

SCHAFFERS, A. P. 2002. Soil, biomass, and management of semi-natural vegetation. Plant Ecology 158:229-246.

Stueter, A. A., and G. R. McPherson. 1997. Fire as a physical stress. In: D. J. Bedunah [ED.]. Wildland plants: physiological ecology and developmental morphology. Denver, CO, USA: Society for Range Management. p. 550-579.

StURGIS, D. L. 1993. Soil-water and vegetation dynamics through 20 years after big sagebrush control. Journal of Range Management 46:161-169.

TAusch, R. J., AND N. E. West. 1995. Plant species composition patterns with differences in tree dominance on a southwestern Utah pinon-juniper site. Fort Collins, CO, USA: USDA Forest Service, Rocky Mountain Forest and Range Experiment Station. General Technical Report RM-258. 226 p.

Ter BraAk, C. J. F. 1986. Canonical correspondence analysis: a new eigenvector technique for multivariate direct gradient analysis. Ecology 67:1167-1179.

ThomAs, G. W. 1982. Exchangeable cations. Methods of Soil Analyses, part 2. In: Chemical and microbiological properties. Agronomy Monograph no. 9. 2nd ed. Madison, WI: Soil Science Society of America. p. 159-161.

Wright, J. M., AND J. C. Chambers. 2002. Restoring sagebrush dominated riparian corridors using alternative state and threshold concepts: biomass and species response. Applied Vegetation Science 5:237-246. 


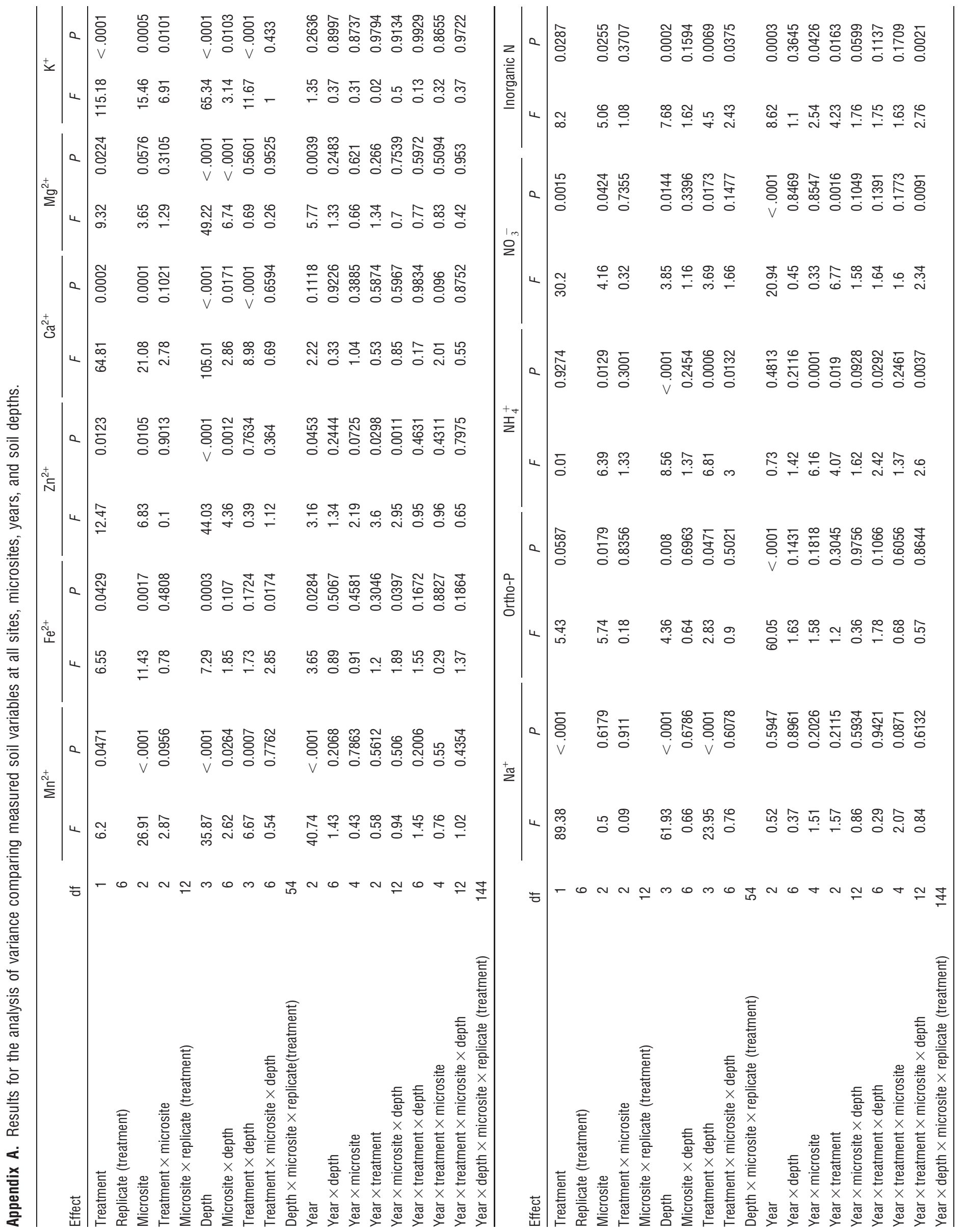




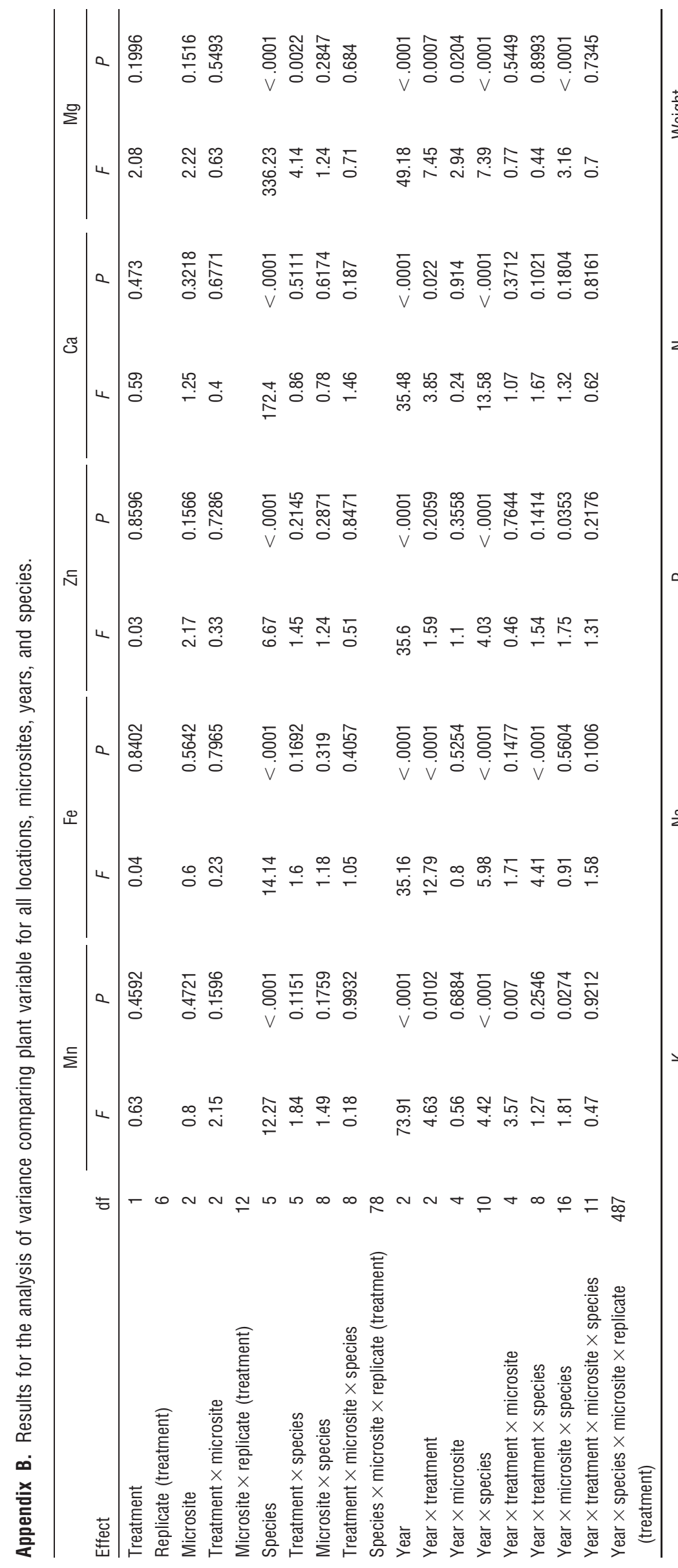

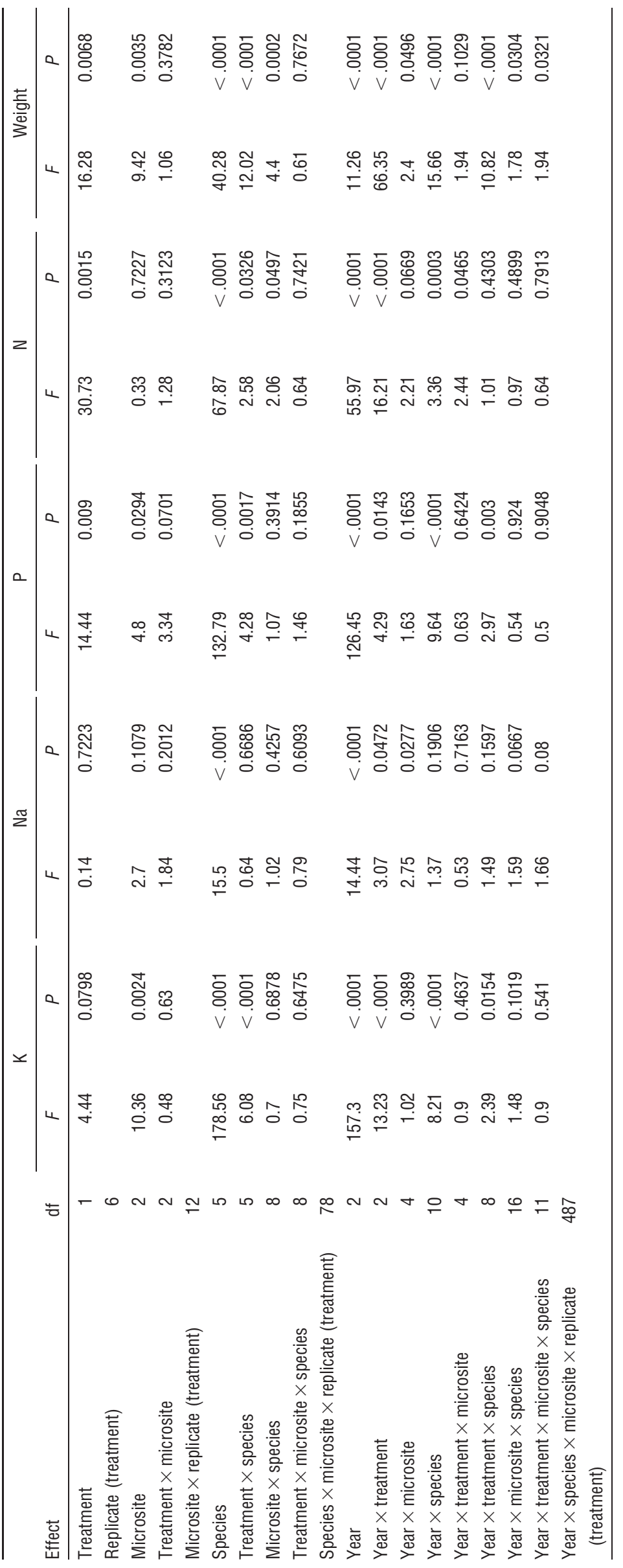

